\title{
A NEW NON-EXTRACTIVE ION-PAIR SPECTROPHOTOMETRIC METHOD FOR THE ASSAY OF ALBENDAZOLE
}

\author{
MARINELA FLOREA ${ }^{1}$, IOANA CLEMENTINA CONSTANTINESCU ${ }^{1 *}$, MIHAELA VIOLETA \\ GHICA $^{2}$, LĂCRĂMIOARA POPA ${ }^{2}$, CORINA-CRISTINA ARAMĂ ${ }^{1}$, ANGELA NEDELCU ${ }^{1}$ \\ “Carol Davila” University of Medicine and Pharmacy, Faculty of Pharmacy, 6 Traian Vuia Street, 020956, Bucharest, Romania \\ ${ }^{\prime}$ Department of Analytical Chemistry, \\ ${ }^{2}$ Department of Physical and Colloidal Chemistry
}

*corresponding author: constantinescu_clementina@yahoo.com

Manuscript received: November 2018

\begin{abstract}
The paper presents a new non-extractive spectrophotometric method for the assay of albendazole (ABZ) as ion pair with Congo red (CR). A soluble and stable ion pair (ABZ-CR) with an absorption maximum at $294 \mathrm{~nm}$ was obtained using a $2 \cdot 10^{-8} \mathrm{M}$ $\mathrm{CR}$ concentration and Britton Robinson (BR) buffer with $\mathrm{pH}=2.5$. The method is linear in the range $2.5-4.7 \mu \mathrm{g} / \mathrm{mL}$, with limits of detection and quantification of $0.09 \mu \mathrm{g} / \mathrm{mL}$ and $0.28 \mu \mathrm{g} / \mathrm{mL}$, respectively. The proposed method was applied to the assay of ABZ in bulk pharmaceutical substance. Because CR is a dye with pharmacological applications used as model in biochemical studies, the research also focused on the mechanism of interaction with ABZ. Spectral changes and physicochemical constants (conductivity, dielectric constant) indicated that ABZ-CR ion pairing takes place at the surface of CR aggregates by electrostatic and charge transfer interactions.
\end{abstract}

\section{Rezumat}

Lucrarea prezintă o nouă metodă spectrofotometrică non-extractivă de dozare a albendazolului (ABZ) ca pereche de ioni cu roșu de Congo (CR). Perechea de ioni (ABZ-CR), solubilă și stabilă, cu maxim de absorbție la $294 \mathrm{~nm}$ s-a obținut folosind o concentrație de $\mathrm{CR}$ de $2 \cdot 10^{-8} \mathrm{M}$ și soluție tampon Britton-Robinson $(\mathrm{BR}) \mathrm{cu} \mathrm{pH}=2,5$. Metoda este liniară pe domeniul de concentrații 2,5 - 4,7 $\mu \mathrm{g} / \mathrm{mL}$, cu limita de detecție de $0,09 \mu \mathrm{g} / \mathrm{mL}$ și limita de cuantificare de $0,28 \mu \mathrm{g} / \mathrm{mL}$. Metoda a fost aplicată la dozarea substanței farmaceutice ABZ. Deoarece CR este un indicator cu proprietăți farmacologice şi folosit ca model în studiile de biochimie, studiul a avut în vedere și stabilirea mecanismului de interacțiune cu ABZ. Modificările spectrale și constantele fizico-chimice (conductivitate, constantă dielectrică) au aratat că perechea de ioni ABZ-CR se formează la suprafața agregatelor de CR prin interacțiuni electrostatice şi transfer de sarcină.

Keywords: albendazole, Congo red, non-extractive, assay, resonance light scattering

\section{Introduction}

ABZ is a benzimidazole derivative, chemicaly: (methyl $\mathrm{N}$-[5-(propylsulfanyl-1-H-benzimidazol-2-yl] carbamate), used as antihelmintic agent [2]. Recent studies indicated it as having antitumor effect in various forms of cancer [18] and Alzheimer disease [29]. Thus, elucidation of action mechanism, obtaining pharmaceutical forms with controlled release [15] and development of new rapid and sensitive assay methods are studies of great interest [12]. The completion of the analytical profile of pharmaceutical substances with the ability to form ion pairs with various counterions is useful mainly for drug control but also for pharmaceutical technology, by obtaining new formulations with predictable biodisponibility, and in pharmacological studies, ion pairing being one of the mechanisms of the absorption [6]. We previously reported ion-pair based determination methods of different pharmaceutical substances $[3,5,6]$. Ion pairs are also known as ionic associations or ionic association complexes. Mechanisms underlying the formation of ion pairs depend on the structure of the interacting ions and reaction media; spectrophotometric techniques are the most used in this regard. Ion pairs formation is based on the electrostatic or hydrophobic interactions, charge transfer and proton transfer [5, 25]. For the drugs assay, widely used are the extractive ion-pair spectrophotometric methods. Extraction is a laborious procedure and the trends are to develop non-extractive (extraction-free) methods. For the determination of ABZ two nonextractive ion pair spectrophotometric methods are reported [23].

The objective of this work was to investigate the ability of ABZ to form ion pairs, in aqueous media, in order to develop a non-extractive spectrophotometric assay method. The dye used as counterion was Congo red (CR), a sulfonated azo dye (3,3'[[1,1'biphenyl]-4,4'- diylbis-(azo)]bis[4-amino-1naphthalene-sulfonic acid] di-sodium salt). 
CR has a fully symmetric structure, only one $\mathrm{pK}_{\mathrm{a}}$ value (4.93 - 5.95) being reported for the two aromatic amino groups [13]. Recent applications of CR in analytical chemistry are ion pair based light scattering methods used for the drug assay [7, 28]. Interesting and studied applications are the pharmacological ones, being considered to have neuroprotective effect in a variety of models of neurodegenerative diseases [29] and it has the ability to selectively interact with antigencomplexed antibodies, aspect that indicate the possibilities for its use in the targeted transport of drugs [22].

The study also focused on the mechanism of interaction between $\mathrm{ABZ}$ and $\mathrm{CR}$. The ionic association equilibrium between ABZ and CR was studied using spectrophotometric methods, namely UV-VIS absorption and resonance light scattering (RLS), and physicochemical constants (conductivity, dielectric constant). The influence of the experimental conditions on the interaction with $\mathrm{CR}$ was studied starting from the physicochemical characteristics (lipophilicity, acidity) of ABZ. A new non-extractive ion-pair spectrophotometric method for the determination of ABZ was developed.

\section{Materials and Methods}

\section{Reagents and solutions}

A 2 mM stock solution of ABZ (Sigma - Aldrich) was prepared by dissolving the appropriate amount of substance in acetic acid (analytical grade $-99.8 \%$, $1.05 \mathrm{~g} / \mathrm{cm}^{3}$ ). Working solutions were prepared by diluting $5 \mathrm{~mL}$ of stock solutions to $50 \mathrm{~mL}$ using the same solvent.

$\mathrm{CR}$, solution A, was prepared by dissolving $0.1000 \mathrm{~g}$ substance (Scharlau) in water using a $250 \mathrm{~mL}$ volumetric flask. Solution B was prepared by diluting $8.8 \mathrm{~mL}$ solution A in water, using a $25 \mathrm{~mL}$ volumetric flask.

Britton-Robinson (BR) buffer was prepared by mixing $0.04 \mathrm{M}$ phosphoric acid, $0.04 \mathrm{M}$ acetic acid and 0.04 $\mathrm{M}$ boric acid in $1 \mathrm{~L}$ of water. The $\mathrm{pH}$ of the buffer was adjusted to $2-3.5 \mathrm{pH}$ values with $0.2 \mathrm{M} \mathrm{NaOH}$ solution.

All reagents were of analytical grade and double distilled water was used throughout.

Apparatus

UV-Vis spectra were recorded on a Jasco V-730 spectrophotometer, in the range $300-700 \mathrm{~nm}$.

For the RLS spectra, a dual monochromator spectrofluorimeter (LS50B from Perkin Elmer, Inc., USA) was used, in the synchronous scanning mode, at the same excitation and emission wavelengths $\left(\lambda_{\text {excitation }}=\right.$ $\left.\lambda_{\text {emission }}\right)$, using a $1 \mathrm{~cm}$ path length quartz cell and $1 \%$ emission attenuation filter in the emission beam.

Conductivity measurements were performed at a Conductivity Meter, DK 60GK and dielectric constant was determined on a Radelkis Dilelectric Constant Meter.

General procedure

In a $10 \mathrm{~mL}$ volumetric flask appropriate amounts of ABZ working solutions, acetic acid to $2 \mathrm{~mL}, 6 \mathrm{~mL}$ of water, $1 \mathrm{~mL}$ of BR buffer solution $(\mathrm{pH}=2.5)$ and $1 \mathrm{~mL}$ of $\mathrm{CR}$, solution $\mathrm{B}$, were successively added; the mixture was thoroughly shaken. The reagent blank was prepared using the same procedure, without ABZ.

Validation procedure

Validation of the method was performed according to ICH Q2(R1) [8] instructions for linearity, detection and quantification limits, precision (repeatability, intermediate precision) and accuracy. Assay of ABZ in bulk pharmaceutical substance ABZ pharmaceutical substance was a gift from Arena Group SA, Romania. Determinations were performed according to the procedure described at General procedure section.

\section{Results and Discussion}

Solvent selection

$\mathrm{ABZ}$ is a hydrophobic compound, highly soluble in dimethylsulphoxide, acetic acid and chloroform [10]. In order to develop a non-extractive ion-pair spectrophotometric method, a water miscible solvent was selected. Acetic acid is a protogenic solvent with levelling effect of the basic function of dissolved substances. ABZ is an amphiprotic compound. In water, $\mathrm{pKa}$ values reported corresponds to deprotonation of amino group at position $1\left(\mathrm{pK}_{\mathrm{a} 1}: 9.79-10.4\right)$ and to deprotonation of protonated nitrogen at position 3 $\left(\mathrm{pK}_{\mathrm{a} 2}: 2.90\right.$ - 3.37) [10]. Thus in acidic media ABZ exists in cationic form, $\mathrm{ABZH}^{+}$. In the same solvent, due to the two $-\mathrm{SO}_{3}{ }^{-}$groups, $\mathrm{CR}$ exists in anionic form. The protonated amino groups can form ion pairs with $\mathrm{CH}_{3} \mathrm{COO}^{-}$(Figure 1).<smiles>Nc1c(N=Nc2ccc(-c3ccc(N=Nc4cc([S+](=O)(=O)[O-])c5ccccc5c4N)cc3)cc2)cc([S+](=O)([O-])[O-])c2ccccc12</smiles>

Figure 1.

$\mathrm{CR}$ as ionized form in $\mathrm{CH}_{3} \mathrm{COOH}$

Thus, ABZ-CR ion pairing can take place due to the electrostatic attraction between $\mathrm{ABZH}^{+}$and $\mathrm{CR}^{2-}$ :

$$
2 \mathrm{ABZH}^{+}+\mathrm{CR}^{2-}=\left(\mathrm{ABZH}^{+}\right)_{2} \cdot \mathrm{CR}^{2-}
$$

Dielectric constant of $\mathrm{CH}_{3} \mathrm{COOH} / \mathrm{H}_{2} \mathrm{O}$ mixtures According to the Bjerrum model, ion pairs were considered only in solvents with relative permittivity between 10 and 40 [27]. Solvent mixtures have characteristic dielectric constants. In order to evaluate the mechanism of the ion pairing between $\mathrm{ABZ}$ and 
FARMACIA, 2019, Vol. 67, 3

$\mathrm{CR}$, dielectric constants for different mixtures of $\mathrm{CH}_{3} \mathrm{COOH} / \mathrm{H}_{2} \mathrm{O}$ were determined. The obtained results are presented in the Table I.

Table I

Dielectric constant values for $\mathrm{CH}_{3} \mathrm{COOH} / \mathrm{H}_{2} \mathrm{O}$ mixtures

\begin{tabular}{|c|c|c|}
\hline $\mathrm{CH}_{3} \mathrm{COOH} / \mathrm{H}_{2} \mathrm{O}(\mathrm{v} / \mathrm{v})$ & $\mathrm{CH}_{3} \mathrm{COOH}(\%)$ & $\varepsilon$ \\
\hline $2 / 8$ & 21 & 20.3 \\
\hline $1.5 / 8.5$ & 15.75 & 20.5 \\
\hline $1 / 9$ & 10.50 & 22.8 \\
\hline $0.5 / 9.5$ & 5.25 & 23.5 \\
\hline $0 / 10$ & 0 & 72 \\
\hline
\end{tabular}

Values of the determined parameter confirm that in $\mathrm{CH}_{3} \mathrm{COOH} / \mathrm{H}_{2} \mathrm{O}$ mixture the main driving force for $\mathrm{ABZ}-\mathrm{CR}$ ion pairing is electrostatic interaction.

The influence of $p H$

Further, ABZ-CR ion pairing was studied without and with buffer system added. The optimum $\mathrm{pH}$ of the buffer system was selected by analysing the changes in the UV-Vis absorption spectra registered for solutions of ABZ $2.86 \mu \mathrm{g} / \mathrm{mL}$, CR $2 \cdot 10^{-8} \mathrm{M}$ and ABZ-CR ion pair, using as solvent a $\mathrm{CH}_{3} \mathrm{COOH} / \mathrm{H}_{2} \mathrm{O}$ $2 / 8(\mathrm{v} / \mathrm{v})$ mixture and $\mathrm{BR}$ buffer with $\mathrm{pH}$ values between 2 and 3.5. For the buffer with $\mathrm{pH}=2.5$, changes in the absorption spectra indicated ABZCR formation (Figure 2).

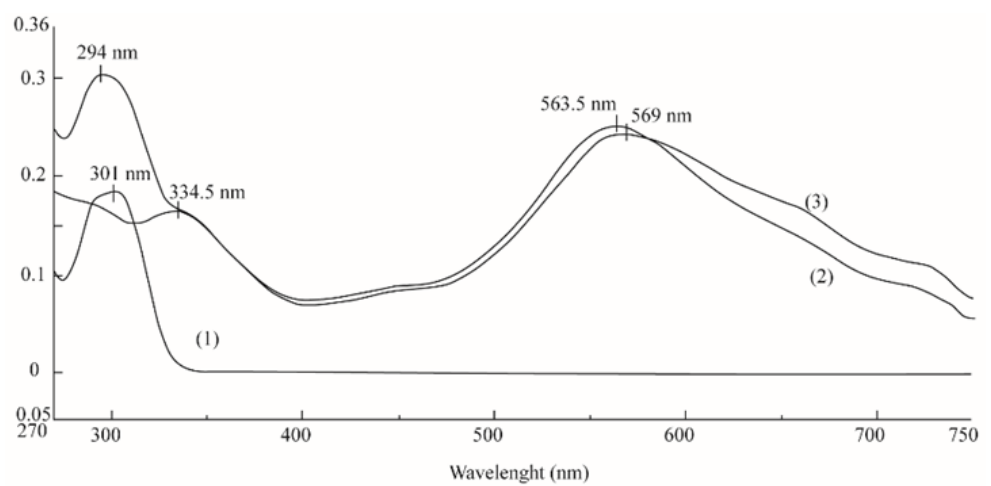

Figure 2.

Absorption spectra for (1) ABZ $2.86 \mu \mathrm{g} / \mathrm{mL}$, (2) CR 2 $10^{-8} \mathrm{M}$ and (3) ABZ-CR ion-pair

In the $\mathrm{CR}$ absorption spectrum, two maximum appeared at 334 and $563 \mathrm{~nm}$. After the interaction with ABZ, maximum at $563 \mathrm{~nm}$ was red-shifted with $6 \mathrm{~nm}$, at $569 \mathrm{~nm}$. ABZ has a maximum at $301 \mathrm{~nm}$, blue and hyperchromically shifted at $294 \mathrm{~nm}$, when the ABZ$\mathrm{CR}$ ion pair is formed, indicating that the charge transfer takes place between the interacting ions [5]. For the further determinations, the maximum at $294 \mathrm{~nm}$ was considered.

\section{Conductivity measurements}

Electrical conductivity measurements provide experimental evidence for the existence of ion pairs in solution. A decrease of the observed conductivity can be attributed to ion pairing [4]. Conductivity values determined for the $\mathrm{CR} 2 \cdot 10^{-8} \mathrm{M}$ and $\mathrm{ABZ}-\mathrm{CR}$, solutions in $\mathrm{CH}_{3} \mathrm{COOH} / \mathrm{H}_{2} \mathrm{O} 2 / 8(\mathrm{v} / \mathrm{v})$, decrease as $\mathrm{ABZ}$ concentration increase confirming thus the ion pair formation by electrostatic interaction (Table II).

Table II

Conductivity values for $\mathrm{CR}$ and $\mathrm{ABZ}-\mathrm{CR}$ ion pair solutions

\begin{tabular}{|c|c|}
\hline $\mathrm{CH}_{3} \mathrm{COOH} / \mathrm{H}_{2} \mathrm{O} 2 / 8(\mathrm{v} / \mathrm{v})$ & Conductivity $(\mu \mathrm{s} / \mathrm{cm})$ \\
\hline $\mathrm{CR}$ & 1940 \\
\hline $\mathrm{ABZ}-\mathrm{CR}(2.38 \mu \mathrm{g} / \mathrm{mL})$ & 1920 \\
\hline $\mathrm{ABZ}-\mathrm{CR}(3.34 \mu \mathrm{g} / \mathrm{mL})$ & 1909 \\
\hline
\end{tabular}

\section{The influence of reagents addition order}

Experiments showed that the reagents addition order has an important influence on the solubility of the ionic association ABZ-CR [7]. The optimum reagents addition order is (1) ABZ solution, (2) $\mathrm{H}_{2} \mathrm{O}$, (3) BR buffer and (4) CR solution.

The influence of concentration of $C R$

The influence of CR concentration was studied in the range $0.5-3 \cdot 10^{-8} \mathrm{M}$. Soluble and stable ion pair was obtained for the concentration $2 \cdot 10^{-8} \mathrm{M}$.

Stability of the ABZ-CR ion pair

The stability of the ABZ-CR ion pair was studied within an hour by determining the absorbance at $294 \mathrm{~nm}$ from 10 to 10 minutes. The absorbance values did not undergo significant changes indicating the stability of the ion-pair.

The mechanism of ABZ-CR ion pair formation The interaction mechanism underlying the formation of ABZ-CR ion pair was established by correlating the data obtained from absorption spectrometry with those obtained from RLS technique and physicochemical constants (dielectrical constant, conductivity). The structure of CR suggests that it can react through a combination of hydrophobic and electrostatic interactions [11]. In addition, it has the property to self-associate forming supramolecular assemblies of a polyanionic nature [16] or rod-like micelles due to parallel stacking of the aromatic groups [19]. In water 
solutions this property is manifested at concentrations higher than $5 \cdot 10^{-6} \mathrm{M}$, low $\mathrm{pH}$ values or high ionic strength. In order to establish the mechanism of interaction with $\mathrm{ABZ}$ we have investigated the influence of the used reaction media on the aggregation of CR. For the purpose, RLS spectrometry was used. RLS is a useful spectroscopic technique for the study of the conformational and volume changes of the molecules, especially because of the aggregation phenomena. It was first predicted by Placzek in the mid-thirties. Later it was studied as resonance enhanced Rayleigh scattering (RERS) for diphenylpolyenes [1], for a series of coumarin dyes [21], for aggregates containing porphyrins [17]. When chemical interactions lead to an increase of the molecular volume, changes appeared in the steadystate elastic scattering (Rayleigh) spectrum and correlate with the absorption and scattering spectra of the parent molecule as follows: (a) if the volume remains within the Rayleigh range (i.e. for larger molecules), then the light scattering spectrum has the same shape as the parent molecule, the emission intensity increases, and there are no correlations with the absorption spectra [26] and, (b) if the volume is considerably greater than that associated to Rayleigh scattering (i.e., for aggregates or ionic associations), then new bands appear in the scattering spectrum, largely correlated to the absorption UV-VIS bands of the molecules alone. In this case, the intensity of the scattered light is greatly enhanced due to a resonance effect and no longer obeys the Rayleigh law ( $\mathrm{I} \sim \lambda^{-4}$, where $\lambda$ is the excitation wavelength) [17].

RLS spectra registered for solutions containing CR $2 \cdot 10^{-8} \mathrm{M}$ and $1 \mathrm{~mL} \mathrm{BR}$ buffer $\mathrm{pH}=2.5$ and increasing amounts of acetic acid are presented in Figure 3.

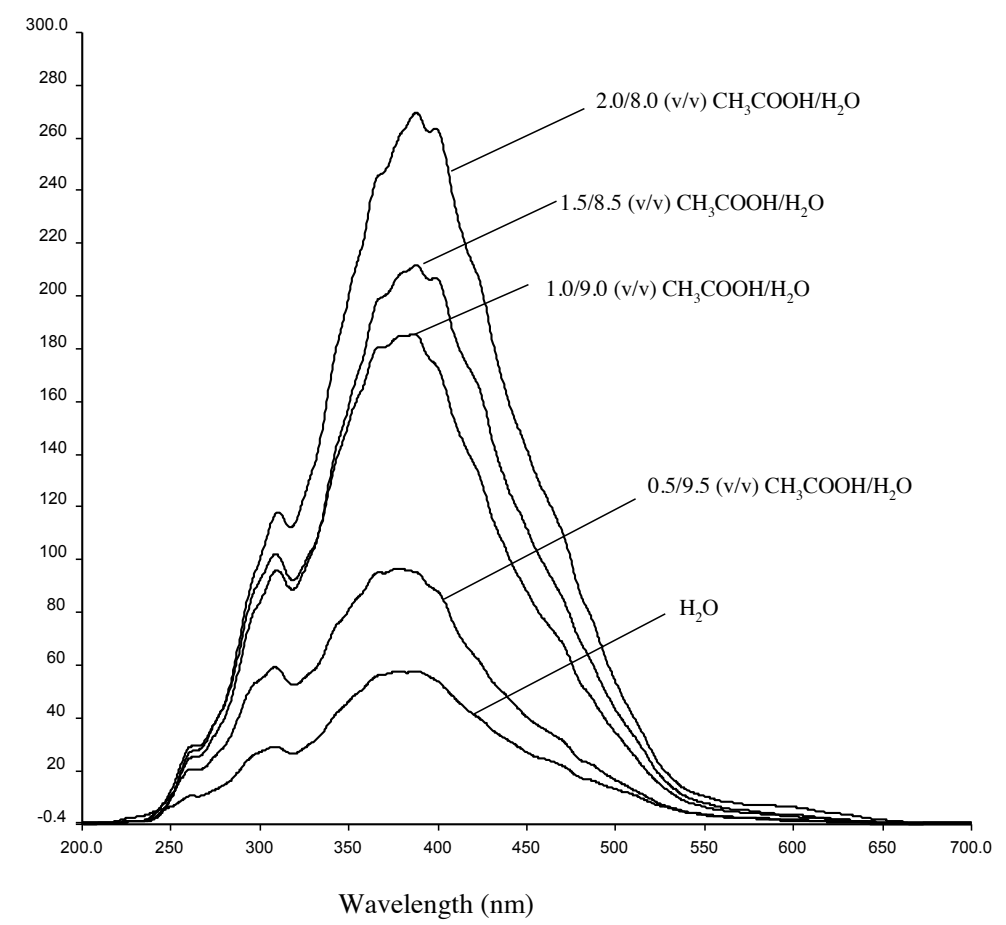

Figure 3.

RLS spectra for CR solutions $\left(2 \cdot 10^{-8} \mathrm{M}\right)$ in $\mathrm{CH}_{3} \mathrm{COOH} / \mathrm{H}_{2} \mathrm{O}$ solvent mixtures

It can be noticed a great intensity enhancement of the scattered light for the $\mathrm{CR}$ solution prepared using as solvent $\mathrm{CH}_{3} \mathrm{COOH} / \mathrm{H}_{2} \mathrm{O}$ mixture 2/8 (v/v), with a maximum at $375 \mathrm{~nm}$, maximum that does not correlate with the absorption spectra. These changes indicate the aggregation of CR molecules [26].

$\mathrm{UV}-\mathrm{V}$ is spectra were registered for solutions with constant concentration of $\mathrm{CR}\left(2 \cdot 10^{-8} \mathrm{M}\right)$ and increasing concentration of ABZ. It was observed an increase of the absorbance measured at $294 \mathrm{~nm}$ with the increasing $\mathrm{ABZ}$ concentrations until it reached a plateau (above $4.3 \mu \mathrm{g} / \mathrm{mL} \mathrm{ABZ)} \mathrm{(Figure} \mathrm{4).} \mathrm{This} \mathrm{can}$ be an indication that the ABZ-CR ion pair is formed at the surface of CR aggregates.

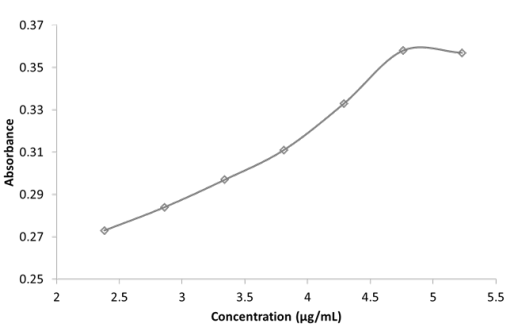

Figure 4.

Absorbance variation at $294 \mathrm{~nm}$ from ABZ-CR ion pair spectra depending on $\mathrm{ABZ}$ concentration 
Based on the presented experimental data, it can be stated that the formation of ABZ-CR ion pair takes place at the surface of the CR micelles because of electrostatic and hydrophobic interactions.

Method validation

Validation parameters were determined by measuring the absorbance at $294 \mathrm{~nm}$ for solutions of ABZ-CR ion pair prepared as described in General procedure section.

The linearity was investigated between $2 \mu \mathrm{g} / \mathrm{mL}$ and $5.5 \mu \mathrm{g} / \mathrm{mL} \mathrm{ABZ}$ and the method was found to be linear between $2.5 \mu \mathrm{g} / \mathrm{mL}$ and $4.7 \mu \mathrm{g} / \mathrm{mL}$.

The limits of detection $(0.09 \mu \mathrm{g} / \mathrm{mL})$ and quantification $(0.28 \mu \mathrm{g} / \mathrm{mL})$ were evaluated on the basis of the standard deviation obtained for the standard (measured in six replicates) and the slope.

The precision, expressed as the relative standard deviation of the determined content measured in the same day, by the same analyst on six replicates, was found to be $0.55 \%$. The intermediate precision, expressed as the relative standard deviation of the determined content measured in different days by different analysts, was found to be $0.80 \%$.

Accuracy was evaluated as recovery of ABZ within the range $80 \%$ to $120 \%$ of the considered concentration. The accuracy of the method was established to be $100.07 \pm 0.42$. A summary of the validation parameters is given in Table III.

Table III

Summary of the validation parameters

\begin{tabular}{llc}
\hline \multicolumn{1}{c}{ Validation criterion } & \multicolumn{1}{c}{ Parameter } & Results \\
\hline Linearity & Regression parameters & $\mathrm{y}=0.0291 \mathrm{x}-0.1862$ \\
& Correlation coefficient & 0.9969 \\
Range & & $2.5-4.7 \mu \mathrm{g} / \mathrm{mL}$ \\
Detection limit & & $0.09 \mu \mathrm{g} / \mathrm{mL}$ \\
Quantification limit & & $0.28 \mu \mathrm{g} / \mathrm{mL}$ \\
Accuracy & & $100.07 \pm 0.42$ \\
Precision & Repeatability & $\mathrm{RSD}=0.55 \%$ \\
& Reproducibility & $\mathrm{RSD}=0.80 \%$ \\
\hline
\end{tabular}

The validation parameters indicate that the

non-extractive ion pair spectrophotometric sensitivity of the method is comparable with the

published methods (Table IV).

Table IV

Comparison of the performance of the present work with published methods

\begin{tabular}{lccc}
\hline \multicolumn{1}{c}{ Counterion } & LOQ $(\boldsymbol{\mu g} / \mathbf{m L})$ & Linearity range $(\boldsymbol{\mu g} / \mathbf{m L})$ & Reference \\
\hline Bromophenol blue & 0.02 & $1.5-21.0$ & 23 \\
Bromothymol blue & 0.49 & $2.0-32.0$ & 23 \\
Congo red & 0.28 & $2.5-4.7$ & Our study \\
\hline
\end{tabular}

\section{Analytical applications}

The aim of any rule governing the production, distribution and use of medicinal products must be the safeguard of pharmaceutical health [24]. In the field of drug analysis, the analytical investigation of bulk drug materials is a very important area of research [14]. In Pharmacopoeias, the official documents that regulate the quality of medicines [20], UV spectroscopic assay methods represent approximately $10 \%$ of the assay method of bulk drug materials [14].

The proposed assay method of ABZ as ion pair with $\mathrm{CR}$, was applied for the determination of the drug in bulk pharmaceutical substances. Determinations were performed as described in General procedure section. The average recovery obtained was $100.31 \%$.

Reported plasmatic concentration of $\mathrm{ABZ}$ was $0.918 \mu \mathrm{g} / \mathrm{mL}$ [9]. The quantification limit of the proposed assay method was $0.25 \mu \mathrm{g} / \mathrm{mL}$ thus being suitable for the identification of $\mathrm{ABZ}$ in plasma. Limitations of the proposed method owe to the solvent used for the solubilisation of ABZ. Acetic acid partially dissolves the excipients from pharmaceutical formulations, which interferes the determination by modifying the ionic strength in the reaction medium.

\section{Conclusions}

A new non-extractive spectrophotometric method for ABZ assay was developed based on the ABZ-CR ion pair with characteristic absorbance at $294 \mathrm{~nm}$. A quantitative ionic association equilibrium was obtained in a binary solvent $\left(\mathrm{CH}_{3} \mathrm{COOH} / \mathrm{H}_{2} \mathrm{O} 2 / 8\right.$ $(\mathrm{v} / \mathrm{v})$ mixture), using a $2 \cdot 10^{-8} \mathrm{M}$ concentration of $\mathrm{CR}$ and $\mathrm{pH}=2.5 \mathrm{BR}$ buffer.

Spectrophotometric data correlated with physicochemical constants of the reaction medium indicated that CR exists as large aggregates. Consequently, the ABZ-CR ion pair is formed at the surface of "micelles" because of the electrostatic and charge transfer interactions. The main advantage of the study is that completes the analytical profile of $\mathrm{ABZ}$ with data regarding the ability to form ion pairs in aqueous solutions with CR, dye used as model in biochemical studies. Experimental data regarding the interaction mechanisms of ABZ with biological active 
substances can be used as models for studying the antitumoral mechanism.

\section{References}

1. Bauer DR, Hudson B, Pecora R, Resonance enhanced depolarized Rayleigh scattering from diphenylpolyenes. J Chem Phys., 1975; 63: 588-589.

2. Clarke EGC, Clarke's analysis of drug and poisons in pharmaceuticals, body fluids and postmortem material. $4^{\text {th }}$ Edition. London. The Pharmaceutical Press., 2011; 841.

3. Constantinescu IC, Florea M, Neagu AF, Development of a spectrophotometric method for determination of fluoxetine hydrochloride in bulk and pharmaceutical dosage forms. Farmacia, 2015; 63(6): 816-820.

4. Dunkhin A, Parlia S, Ion-pair conductivity theory fitting measured data for various alcohol-toulene mixtures across entire concentration range. $J$ Electrochem Soc., 2015; 162: H256-H263.

5. Florea M, Ilie M, Ion-pair Spectrophotometry in Pharmeceutical and Biomedical Analysis: Challenges and Perspectives. In Spectroscopic Analyses Developments and Applications. InTech, Croatia, 2017; 173-192.

6. Florea M, Monciu CM, Ilie M, Dtermination of nimesulide by Ion Pair High-Performance Liquid Chromatography using Tetrabutylammonium as the Counterion. Anal Lett., 2015; 48: 328-339.

7. Florea M, Monciu CM, Ilie M, Resonance Rayleigh scattering study of streptomycin - Congo red ionic association in view of analytical application. Farmacia, 2014; 62(2): 318-328.

8. ICH Q2(R1). Validation of analytical procedures: Text and methodology Q2(R1), ICH Harmonized Tripartite Guideline, International Conference on Harmonization of Technical Reguirements for Registration of Pharmaceuticals for Human Use, Incorporated in November, 2005. Geneva: ICH Secretariat.

9. Jung H, Hurtado M, Sanchez M, Medina MT, Sotelo J, Plasma and CSF levels of albendazole and praziquantel in patients with neurocysticercosis. Clin Neuropharmacol., 1990; 13: 559-564.

10. Jung H, Medina LG, Fuentes I, Moreno-Esparza R, Absorption studies of albendazole and some physicochemical properties of the drug and its metabolite albendazole sulphoxide. J Pharm Pharmacol., 1998; 50: 43-48.

11. Khurana R, Uversky VN, Nielsen L, Fink AL, Is Congo red an amyloid specific dye?. J Biol Chem., 2001; 276(25): 22715-22721.

12. Li Q, Tan X, Fu L, Liu Q, Tang W, A novel fluorescence and resonance Rayleigh scattering probe based on quantum dots for the detection of albendazol. Anal Meth., 2015; 7: 614-620.

13. Lorenc-Grabowska E, Gryglewicz G, Adsorption characteristics of Congo Red on coal-based mesoporous activated carbon. Dye and Pigments, 2007; 74: 34-40.

14. Misiuk $\mathrm{W}$, The role of assay methods in characterizing the quality of bulk pharmaceuticals. $J$ Pharm Bioallied Sci., 2010; 2: 88-92.
15. Noorani L, Stenzel M, Liang R, Pourgholami MH, Albumin nanoparticles increase the anticancer efficacy of albendazole in ovarian cancer xenograft model. $J$ Nanobiotech., 2015; 13(25): 1-12.

16. Panczyk T, Wolski P, Jagusiak A, Drach M, Molecular dynamics study of Congo red interaction with carbon nanotubes. RSC Adv., 2014; 4: 47304-47312.

17. Pasternack RF, Bustamante C, Collings PJ, Giannetto A, Gibbs EJ, Porphyrin assemblies on DNA as studied by a resonance light-scattering technique. $J$ Am Chem Soc., 1993; 115: 5393-5399.

18. Pourgholami MH, Cai ZY, Badar S, Wangoo K, Poruchynsky MS, Morris DL, Potent inhibition of tumoral hypoxia-inducible factor 1alpha by albendazole. BMC Cancer, 2010; 10(143): 1-7.

19. Skowronek M, Stopa B, Koniczny L, Rybarska J, Piekarska B, Szneler E, Bakaalarski G, Roterman I, Self-assembly of Congo Red - A theoretical and experimental approach to identify its supramolecular organization in eater and salt solution. Biopolymers, 1998; 46: 267-281.

20. Stancu E, Carata A, Taerel AE, Soroceanu V, Rais C, Stancu E, The study of Pharmacopoeias used in the Romanian area in XVII-XX ${ }^{\text {th }}$ centuries: evolution of proportions for drug substances and pharmaceutical preparations. Farmacia, 2014; 62(5): 1037-1048.

21. Stanton SG, Pecora R, Hudson BS, Resonance enhanced dynamic Rayleigh scattering. J Chem., 1981; 75: 5615.

22. Stopa B, Jagusiak A, Konieczny L, Piekarska B, Rybarska J, Zemanek G, Krol M, Piwowar P, Roterman I, The use of supramolecular structures as protein ligands, J Mol Model., 2013; 19(11): 4731-4740.

23. Swamy N, Basavaiah K, Use of Two Sulfonphthalein Dyes for the Sensitive and Selective Extraction-Free Spectrophotometric Assay of Albendazole in Bulk Drug and in Tablets. ISRN Analytical Chemistry, 2013; 2013(Art ID734027): 1-11.

24. Taerel AE, Soroceanu V, Rais C, Trends in the evolution of the annual classified list of medicines between 1989-2012. Farmacia, 2013; 61(5): 948-956.

25. Taşkin D, Erensoy G, Sungur S, Optimized and validated spectrophotometric determination of butamirate citrate in bulk and dosage forms using ion-pair formation with methyl orange and bromothymol blue. Farmacia, 2017; 65(5): 761-765.

26. Yguerabide J, Yguerabide EE, Light-scattering submicroscopic particles as highly fluorescent analogs and their use as tracer labels in clinical and biological applications. Anal Biochem., 1998; 262: 137-156.

27. Yizhak M, Glenn H, Ion Pairing. Chem Rev., 2006; 106: 4585-4621.

28. Zeng Y, Cai L, Wang H, Li L, You W, Guo L, Chen $\mathrm{G}$, Resonance light scattering study on the interaction between quinidine sulfate and Congo red and its analytical application. Luminescence, 2010; 25(1): 30-35.

29. Zhang KA, Li Y, A new molecular model for Congo red $-\beta$ amyloid interaction: Implications for diagnosis and inhibition of brain plaque formation in Alzheimer's disease. Proc SPIE, Biosensing and Nanomedicine VIII, 2015; 95500X: 1-11. 